\title{
Antara Agama dan Imajinasi: Identitas Simbol Ibadah dalam Perspektif Postkomunikasi, Postspiritualitas, dan Hiperspiritualitas
}

\author{
Muslih Aris Handayani1 ${ }^{1, *}$, Mukti Ali $^{2}$ \\ 1 Institut Agama Islam Negeri Ponorogo, Indonesia; e-mail: aris.handayani@yahoo.com \\ 2 Institut Agama Islam Negeri Salatiga, Indonesia, e-mail: muktiali@iainsalatiga.ac.id \\ * Correspondence
}

Received: 2020-03-26; Accepted: 2020-05-27; Published: 2020-05-30

\begin{abstract}
The practices of worship involve the relationship between humans and themselves, humans and humans, humans and God, and even the relationship between humans and the environment in which they live. With the power of human imagination, when the relationships are practiced properly according to God's direction, then there comes surrender, obedience, and devotion in worshiping God. Spiritual hyperreality or hyperspirituality has created practices of worship that are based on simulating pure rituals as taught by prophets, even though they are ritual formations far from the prophetsnes. Because of the signs of worship practice are based on simulations or self-imaginations, then what appears is falsehood and lies on the signs of the practice of worship. This paper intends to unmask hyperreality in spiritual activities that have been considered sacred. This paper uses semiotics as its approach, especially those introduced by Bartes, Piliang and Baudrillard. this study found that when the practice of worship has been separated from it's pure rituals as taught by prophets and formed a simulation, the practice of worship is only a means of imaging, style personality, and reproduction machinery.
\end{abstract}

Keywords: Imagination; Worship; Hyperspirituality; and Symbolic Identity.

Abstrak: Praktek-praktek ibadah itu menyangkut relasi manusia dengan dirinya, manusia dengan manusia, manusia dengan Tuhan, bahkan relasi manusia dengan lingkungan tempat ia hidup. Ketika relasi-relasi itu dipraktekkan secara baik sesuai arahan Tuhan, ditambah dengan daya imajinasi manusia, maka akan muncul kepasrahan, kepatuhan, dan kekhusyuan dalam beribadah kepada Tuhan. Namun hiperrealitas spiritual atau hiperspiritualitas telah menjungkir balikkan keadaan. Hiperspiritualitas telah menciptakan praktek-praktek ibadah bentukan yang jauh dari ajaran kenabian. Ia bukan praktek ibadah yang murni melainkan sekedar simulasi dari ritual ibadah yang sejati yang diajarkan oleh nabi. Praktek ibadah berdasarkan simulasi atau imajinasi diri ini, akan memunculkan kepalsuan dan kebohongan sebagai tanda-tandanya. Tulisan ini bermaksud membongkar topeng hiperrealitas dalam wilayah spiritual yang selama ini dianggap sakral. Tulisan ini menggunakan semiotika sebagai pendekatannya, terutama yang diperkenalkan oleh Bartes, Piliang dan Baudrillard. Hasil studi menunjukkan bahwa ketika praktek ibadah lepas dari aslinya dan membentuk simulasi maka praktek ibadah hanya akan menjadi sekedar ajang pencitraan, personalitas gaya, dan mesin reproduksi kesombongan.

Kata Kunci: Imajinasi; Ibadah; Hiperspiritualitas; dan Identitas Simbolik

\section{Pendahuluan}

Dunia modern dan proses modernisasi telah membawa manusia pada era teknologi, digitalisasi realitas-realitas sosial yang awalnya bersifat konvensional, serta perubahan dari dunia manusia ke realitas robotic (Green et al., 2008). Ia juga sudah membawa manusia pada simulasi dan rekayasa teknologi, dan bioteknologi dalam bingkai dunia manusia yang tersimulasi. Manusia akhirnya tidak sadar bahwa dirinya telah menjadi robot akibat sistem sosial yang telah terkonstruksi oleh kekuasaan 
dan kewenangan yang dimiliki oleh segelintir manusia yang dominan. Perubahan sosial, teknologi, dan kebudayaan telah membentuk satu komando sistemik dan rutinitas kehidupan yang jauh dari nilai, etika, norma, dan hukum yang menghargai hak-hak personal, kelompok, kaum minoritas, dan nilai-nilai kemanusiaan. Pada tataran ini manusia tak ubahnya seperti benda mati atau robot yang dijalankan oleh sistem sosial, birokrasi, lembaga, dan kewenangan atau kekuasaan yang dimiliki oleh sekelompok orang yang dianggap wajar, normal, dan tidak dipermasalahkan oleh publik.

Dengan demikian, karena manusia telah masuk dalam sistem sosial robotik yang telah terkonstruksi oleh berbagai kekuasaan, kewenangan, keangkuhan, dan arogansi individu atau kelompok atas nama jabatan dan birokrasi, maka agama dibutuhkan dan sangat diperlukan untuk mengembalikan perilaku sosial manusia dan perilaku keberagamaan mereka sesuai dengan statusnya sebagai manusia yang memiliki kesadaran, bukan sebagai robot. Dalam pemikiran Piliang, agama lebih dari sekedar aturan hidup dan perilaku sosial. Agama merupakan sebuah tegangan antara kepatuhan dan aturan, antara hasrat dan pembatasan, antara doktrin dan kreativitas, antara ajaran dan imajinasi. Agama memerlukan imajinasi, karena ia adalah proses pembacaan, yaitu pembacaan ayat atau tanda ketuhanan (Amir Piliang, 2011).

Membaca tanda ketuhanan tak mungkin tanpa kapasitas imajinasi, yaitu membayangkan realitas yang ditandai. Agama tidak bisa hidup tanpa peran imajinasi, termasuk imajinasi tentang yang transenden. Akan tetapi, imajinasi yang melampaui batas telah membentuk kreativitas-kreativitas dalam pengamalan agama yang mungkin menyimpang dari tujuan pengamalan ibadah itu sendiri. Seperti otak Einstein yang memunculkan pengetahuan, sedang prakteknya --yang destruktif-merupakan mitos (Barthes, 2015), begitu juga praktek-praktek ibadah sebagai hasil kekuatan otak dalam membaca teks-teks Tuhan. Pembacaan itu telah bercampuk aduk dengan identitas-identitas sosial dan melampaui batas, maka otak dan hasil yang dipraktekkannya tak ubahnya mitos dalam pandangan Barthes.

Dalam pandangan Yasraf Amir Piliang, orang mesti membayangkan Tuhan, malaikat, iblis, syetan, surga, neraka, meskipun tak dianjurkan memanifestasikannya ke dalam wujud-wujud konkret. Keterlibatan manusia dalam bentuk imajinasi akan mempengaruhi perilaku ibadahnya sebagai aktualisasi dalam keberagamaan. Ketika orang menunaikan shalat, zakat, haji, dan puasa, ia akan memaknai perintah ibadah-ibadah tersebut dan melakukannya sesuai daya nalar dan imajinasi atas makna yang ia tangkap dari perintah ibadah-ibadah tersebut. Ketika praktek-praktek ibadah tersebut telah meninggalkan azas kepatuhan kepada Yang Maha Agung, dan kepasrahan serta kekhusyuan telah berganti dengan identitas keberagamaan, bahkan berbaur dengan identitas sosial, maka di situlah praktek ibadah telah keluar dari objek murni ibadah dan membentuk dunianya sendiri dalam area dunia spiritual bentukan yang disebut hiperspiritualitas.

Hiperspiritualitas berkembang dari konsep hiperrealitas. Hiperrealitas dalam pandangan Jean Baudrillard adalah realitas bentukan yang dalam konstruksinya tidak bisa dilepaskan dari produksi dan permainan tanda-tanda yang melampaui realitas aslinya. Hiperrealitas menciptakan suatu kondisi di mana kepalsuan bersatu dengan keaslian, masa lalu berbaur dengan masa kini, fakta bersimpang siur dengan rekayasa, tanda melebur dengan realitas, dan dusta bersenyawa dengan kebenaran (Hendrawan et al., 2018). Hiperrealitas meliputi apa pun yang berkembang dengan sendirinya membentuk realitas baru yang penuh dengan rekayasa (W. Suhaeb \& Ashabul Kahfi, 2016).

Hiperrealitas berkaitan dengan simulasi. Simulasi tidak menutupi kenyataan. Simulasi adalah kenyataan yang menutupi ketiadaan, sehingga seolah-olah simulasi itu adalah nyata (Fitria, 2015). Pada akhirnya, hiperrealitas adalah penciptaan sesuatu melalui model-model, sesuatu yang nyata namun tanpa asal-usul atau realitas yang sejati (Nasrullah \& Rustandy, 2016). Hiperrealitas telah memasuki arena-arena praktek ibadah. Ibadah tidak lagi merepresentasikan pengabdian dan kepatuhan kepada Tuhan, tapi telah membentuk dunianya sendiri. Ibadah palsu ini sehingga secara kasat mata lebih nyata dari aslinya sehingga ia telah lepas dan meninggalkan jauh dunia asli spritual. Pada wilayah ini, praktek ibadah hanyalah ajang pencitraan diri, permainan semiotika, identitas keberagamaan yang jauh dari azas kepatuhan dan kepasrahan. Praktek ibadah seperti ini 
mengokohkan kultuisme seseorang dalam percaturan identitas sosial keberagamaan. Masyarakat menghormati seorang tokoh agama di luar nalar kewajaran, karena kebiasaan mereka menghormati seseorang, hingga pada akhirnya terbentuklah penghormatan yang membabi buta. Karena itu perlu penafsiran, pembacaan, dan pemahaman yang baik akan makna ibadah dan perilku aktualnya. Pemaknaan, pembacaan dan pemahaman baru yang baik akan praktek ibadah dan perilaku yang mengikutinya (postspiritualitas) akan mengembalikan makna ibadah dan perilaku yang akan mengikutinya itu ke jalur hakiki yang telah diperintahkan oleh Tuhan. Ketika ini terjadi, pada akhirnya kekhusyuan dalam beribadah akan direpresentasikan dalam tindakan sosial yang humanis, sesuai dengan nilai-nilai kemanusiaan dan keberagamaan.

Perilaku sosial dan keberagamaan yang baik tidak saja merepresentasikan kehidupan sosial yang baik tapi juga merepresentasikan kekhusyuan seseorang dalam beribadah serta kepatuhannya dan kepasrahan hidupnya kepada Tuhan. Agama bukan saja perintah-perintah Tuhan yang harus dikerjakan manusia, tapi agama juga muncul dalam perilaku dan tindakan sosial yang sesuai dengan ajaran yang ditekstualkan (Kloos \& Moore, 2000; Regnerus \& Uecker, 2007). Pada akhirnya, perilaku beragama seharusnya bukanlah ajang pencitraan sosial, identitas, mesin reproduksi kesombongan, keangkuhan, dan kewibawaan di balik baju identitas keberagamaan seseorang. Tokoh-tokoh keagamaan dan lembaga-lembaga keagamaan seharusnya bukan sekedar identitas personal atau sosial, tapi perilaku keagamaan yang sejati yang betul-betul teraktualisasikan dalam ruang dan waktu. Label tokoh keagamaan dan lembaga keagamaan seharusnya bukanlah permainan identitas personal dan sosial tapi bentuk aktualisasi kepatuhan, kepasrahan, serta kekhusyuan seseorang dalam beribadah dan mengabdi kepada Tuhan. Seorang yang taat dan patuh kepada Allah, perilaku sosialnya akan merepresentasikan kesantunan, kerendahan hati, dan kebaikan layaknya seorang pemuka agama, meskipun ia orang biasa. Pada akhirnya, pemuka dan lembaga agama bukanlah sekedar identitas personal dan sosial, ia harus mencerminkan tindakan sosial dalam kehidupan sehari-hari sebagai bentuk kepatuhan dan pengabdian kepada Tuhan.

\section{Agama dan Hasrat Ketenangan Hidup}

Dalam diri manusia terdapat tiga sisi: manusiawi, hewani, dan ilahi. Sebagai makhluk manusiawi, manusia identik dengan akal (rasionalisme), sarat dengan pengalaman (empirisme), memiliki ide-ide untuk bertahan dan mengembangkan hidup (idealisme). Manusia juga memiliki identitas pribadi (personal identity) dan identitas sosial (social identity). Sebagai makhluk yang hampir mirip dengan dunia binatang, manusia memerlukan makan untuk bertahan hidup, perlu pasangan untuk memenuhi hasrat kebutuhan biologis dan untuk melangsungkan keturunan, serta perlu kenyamanan bertempat tinggal. Dari sisi ilahi, manusia memiliki dan meneladani sifat-sifat ketuhanan seperti kasih sayang, menghormati sesama, menegakkan keadilan, berperilaku baik kepada sesama, lingkungan, dan hewan. Sebagai entitas ilahiah, sebagai makhluk yang diciptakan Tuhan yang berbeda dengan makhluk yang lain, manusia punya kewajiban menghambakan diri kepada Tuhan dalam bentuk praktek-praktek ibadah yang telah digariskan oleh Tuhan. Praktekpraktek ibadah itu menyangkut relasi manusia dengan dirinya, manusia dengan manusia, manusia dengan Tuhan, manusia dengan hewan serta lingkungan tempat ia hidup. Bentuk-bentuk relasi ini telah diajarkan oleh Tuhan baik dalam bentuk tekstual atau kontekstual. etika relasi-relasi itu dipraktekkan dengan baik sesuai arahan Tuhan, ditambah dengan daya imajinasi manusia, maka akan muncul kepasrahan, kepatuhan, dan kekhusyuan dalam beribadah kepada Tuhan. Berdasarkan pemikiran ini, manusia dituntut untuk memberikan perhatian yang seimbang atas pemenuhan ketiga sisi yang dimilikinya itu. Agama (yang termasuk dalam kategori sisi ilahiah), adalah salah satu aspek yang melandasi hidup manusia di samping juga sebagai bentuk aktualisasi diri manusia untuk mengatasi kelemahannya. Agama memiliki sisi kepatuhan dan kepasrahan kepada Tuhan untuk mendapatkan ketenangan hidup.

Nina Winangsih Syam (Winangsih Syam, 2014), setelah memperhatikan berbagai pendekatan untuk melihat agama, akhirnya menyimpulkan bahwa terdapat tujuh teori tentang agama. Pertama, 
animisme dan magis. Penghulu teori ini, yaitu Frazer, berpendapat bahwa bukanlah kebetulan bila dalam kebudayaan primitif, orang yang mengklaim dapat menguasai teknik magis, hampir selalu memegang kekuasaan dan martabat yang tinggi. Karena hal itu memberikan ketenangan, harapan bahkan kepastian bagi masyarakat. Ketika pengaruh magis turun, maka agamalah yang menggantikannya. Kedua, Agama dan kepribadian. Penghulu teori ini, yaitu Freud, berpendapat bahwa kekuatan-kekuatan yang tersembunyi dalam kepribadian manusia telah mendorong mereka untuk menaruh perhatian pada agama. Semua orang terkait dengan alam bawah sadar, dan hampir semua doktrin-doktrin yang diterima manusia menemukan kaitannya dengan unsur kepribadian yang dalam dan tak terperhatikan. Unsur inilah sebetulnya yang membentuk kepercayaan manusia pada agama. Ketiga, masyarakat sebagai yang sakral. Penghulu teori ini, yaitu Emile Durkheim, cenderung melihat agama dalam lensa sosiologis. Baginya agama adalah sesuatu yang bersifat sosial. Ia menegaskan bahwa meskipun sebagai individu, kita bebas membuat pilihan kita sendiri, namun kita melakukannya dalam kerangka sosial yang diberikan kepada kita sejak lahir. Dalam semua kebudayaan, agama adalah bagian yang berharga dari perbendaharaan sosial. Sehingga besar kemungkinan pilihan-pilihan itu dibuat berdasarkan kerangka agama. Keempat, agama sebagai sebuah alienasi. Penghulu teori ini yaitu Karl Max berpandangan bahwa agama adalah sebuah ideologi. Agama, --sebagaimana halnya negara, seni, wacana moral, dan usaha intelektual--, termasuk dalam bangunan masyarakat. Oleh karena itu agama secara fundamental bergantung pada landasan ekonomi. Maka jika ada perubahan dalam kehidupan ekonomi, maka pasti diikuti dengan perubahan agama. Dalam pandangan Marx, kapitalisme telah mendorong perubahan dalam agama. Kelima, agama sebagai realitas yang sakral. Penghulu teori ini, yaitu Mircea Eliade, menyatakan independensi ide dan aktifitas agama. Ia mengakui bahwa psikologi, masyarakat, ekonomi, dan kekuatan yang lain memang telah mempengaruhi agama, tapi agama adalah entitas yang independen. Dalam pandangan Eliade, agama dapat dipahami hanya jika kita mencoba melihatnya dari sudut pandang orang beriman. Perilaku, ide, dan institusi agama harus dilihat dari segi perspektif agama, dari segi yang sakral yang menginspirasinya. Dalam pandangan Eliade, bukanlah yang profan yang mengontrol yang sakral, tapi yang sakrallah yang mengontrol yang profan. Keenam, agama adalah"construct of the heart of society". Penghulu teori ini, yakni Evan Pritchard, lebih menekankan keharusan untuk melakukan pendekatan yang simpatik kepada agama-agama primitif. Menurut Pritchard tidak ada masyarakat yang dapat hidup tanpa sains dan agama, semua kebudayaan selalu membutuhkan konsepsi pikiran dari sains dan "construct of heart" dari agama untuk keberlangsungan hidupnya. Ketujuh, agama sebagai sistem budaya. Penghulu teori ini, yaitu Cliford Geertz, berpendapat jika kita ingin memahami kegiatan budaya, salah satu hal yang terpenting yang harus dilakukan adalah memahami agama.

Dari berbagai teori tentang agama tersebut, ketenangan, kenyamanan, dan kedamaian hidup menjadi titik sentral alasan manusia beragama. Agama, lebih dari sekedar perilaku spiritual dan kepatuhan terhadap tuhan, tapi ia membawa implikasi yang besar terhadap kehidupan manusia. Salah satu yang membedakan antara manusia dan binatang pada umumnya adalah manusia memiliki agama. Secara tekstual, agama berarti tidak kacau. Bila dilihat secara historis dari agama primitif sampai lahirnya agama-agama besar dunia saat ini, keseluruhan agama-agama tersebut memberikan tuntunan dan aturan-aturan tentang kehidupan manusia yang lebih harmonis, damai, dan tenang. Agama menawarkan etika dan moral untuk kelangsungan hidup manusia yang lebih tertata dibandingkan dengan kehidupan binatang pada umumnya.

Pada proses perkembangannya, agar tindakan manusia mencerminkan nilai-nilai agama perlu adanya kreativitas dalam memaknai ajaran-ajaran agama. Kita berperilaku sesuai nilai-nilai agama karena kemampuan kita menangkap makna-makna yang disampaikan oleh agama. Kemampuan memaknai ajaran-ajaran agama yang teraktualisasikan dalam tingkah laku akan membentuk kesadaran beragama dan menjadikan perilaku beragama seseorang lebih bermakna. Kekhusyuan dan kepatuhan kepada tuhan muncul jika perilaku dan aktifitas beragama berdasarkan kesadaran dan kebutuhan akan agama, bukan karena tuntutan atau paksaan. Kesadaran dan kebutuhan beragama akan menghasilkan kepatuhan dan kekhusyuan, sedangkan perasaan yang terbebani oleh tuntutan 
dan kewajiban dalam aktifitas beragama hanya akan memunculkan pencitraan dan identitas-identitas spiritual yang jauh dari kepatuhan dan kepasrahan kepada Tuhan.

\section{Agama dan Imajinasi Dalam Kajian Postspiritualitas dan Hiperspiritualitas}

Agama, jika dianalogikan sebagai ideologi, maka sulit memisahkan antara agama sebagai aturan-aturan hidup manusia yang datangnya dari Tuhan dengan perilaku keseharian umat beragama. Teks-teks atau ayat-ayat Tuhan bisa mengkomunikasikan dirinya di dunia ini dalam kehidupan manusia jika berinteraksi dengan nilai-nilai kesadaran manusia. Postkomunikasi atas ayat-ayat Tuhan dalam kehidupan sosial menghasilkan praktek-praktek keberagamaan yang memiliki nilai-nilai ilahiah (sesuai perintah Tuhan) dan nilai-nilai kemanusiaan (sesuai dengan kemampuan manusia memahami dan menjalankan perintah dan ayat-ayat Tuhan). Teks-teks atau ayat-ayat Tuhan memiliki makna dalam perilaku manusia karena ayat-ayat tersebut berinteraksi dengan kesadaran, pemahaman, serta kemampuan manusia dalam menjalankan ayat-ayat tersebut dalam kehidupan sehari-hari. Aktifitas keagamaan seseorang mencerminkan ideologi dari agama yang dianutnya.

Agama, jika dimaknai sebagai perilaku atau aktifitas-aktifitas keberagamaan seseorang, maka sulit memisahkan antara agama dengan imajinasi seseorang dalam memaknai pesan-pesan atau perintah-perintah dalam agama. Orang beraktifitas sejauh terkait dengan agama yang dianutnya berdasarkan daya imajinasinya dalam memaknai perintah dan larangan dalam agama. Imajinasi dalam pandangan Piliang menyangkut mekanisme psikis dalam melihat, melukiskan, membayangkan, atau memvisualkan sesuatu di dalam struktur kesadaran, yang menghasilkan sebuah citra (image) pada otak. Namun apa yang kita bayangkan dapat berasal dari dunia luar (melalui persepsi) atau di dalam dunia mental itu sendiri (seperti mimpi). Imajinasi adalah struktur mental menyangkut bagaimana seseorang membuat potret dunia (world picture), yaitu konsepsi, representasi, dan makna dunia dengan sudut pandang, perasaan, logika, dan keyakinan tertentu. Apa yang kita bayangkan dapat bersifat internal, yaitu membayangkan diri sendiri, masyarakat, atau bangsa, yang menghasilkan citra diri (self-image), atau membayangkan sesuatu yang eksternal: orang lain, komunitas lain, agama lain, suku lain, atau Tuhan yang menghasilkan citra "yang liyan" (image of others).

Imajinasi diri (self imagination) adalah proses pembayangan diri sendiri, yang dilakukan baik oleh individu, kelompok, bangsa, atau umat. Imajinasi diri individu menghasilkan citra diri (self image) yang menjadi dasar subjektifitas (subjectivity). Jacques Lacan melukiskan proses imajinasi diri melalui metafora keterbelahan (spaltung), ketika lukisan diri individu diproduksi melalui proses identifikasi dengan citra liyan (the others), maka hal itu akan menjauhkannya dari kebenaran dirinya sendiri yang sejati (the truth). Seseorang yang membuat lukisan dirinya dengan memproyeksikan atau mengimajinasikan imajinasikan "yang liyan" (the other), akan ini membuat orang itu terperangkap pada citra palsu (pseudo image). Ia akan terperangkap selamanya di sana. Pada akhirnya pencarian citra diri yang asali akan menjadi sebuah proses yang tak berujung (Amir Piliang, 2011). Karena itulah imajinasi diri cenderung lebih bersifat subjektif dari pada objektif. Imajinasi diri mendorong seseorang terperangkap pada citra palsu tak berkesudahan.

Dalam agama Islam, imajinasi selalu dikaitkan dengan kesadaran akan kenabian, yaitu kesadaran yang mampu menerima nubuat. Imajinasi model ini berkaitan dengan kemamuan memaknai perintah-perintah ibadah berdasarkan pada imajinasi-imajinasi seorang nabi dalam menerima nubuat. Umat seorang nabi menggunakan imajinasi dalam memaknai praktek-praktek ibadah berdasarkan kreatifitas imajinasi nabi dalam menyampaikan makna ajaran agama. Ketika imajinasi model itu coba diterapkan oleh manusia biasa atas praktek-praktek ibadah maka muncullah praktek-praktek ibadah yang terjebak pada realitas citra palsu. Ini karena praktek-praktek ibadah itu didasarkan pada imajinasi diri seseorang secara langsung tanpa melalui imajinasi nubuat. Pada akhirnya, citra palsu akan membentuk kesadaran palsu akan praktek-praktek ibadah yang dilakukannya. Pada tataran ini, mesin reproduksi kesombongan, keangkuhan, dan merasa benar sendiri mulai bermunculan. Praktek-praktek ibadah ini lebih cenderung bersifat subjektif. 
Memahami hiperrealitas atau hiperrealitas spiritualitas pada zaman sekarang ini sangatlah penting karena hiperrealitas spiritualitas sudah memasuki wilayah praktek-praktek ibadah. Spiritualitas sering digunakan bergantian dengan religiusitas. Becker menyatakan bahwa kata spiritualitas, keyakinan, dan sifat ketuhanan sering digunakan dalam literatur yang membahas religiusitas. Hal ini terjadi karena adanya tumpang tindih pengertian mengenai religiusitas dan spiritualitas. Hasil review yang dilakukan oleh Tanyi terhadap literatur mengenai spiritualitas menyimpulkan bahwa spiritualitas adalah pencarian arti dan tujuan hidup yang dilakukan individu baik melalui agama atau bukan agama. Davis menyatakan bahwa spiritualitas berhubungan dengan transendensi tanpa merujuk pada agama tertentu. Sedang religiusitas berkonotasi dengan sistem keyakinan agama tertentu (Wahyuningsih, 2008).

Umberto Eco di dalam Travels in Hyperreality menjelaskan hiperrealitas sebagai sebuah bentuk penjarakan (distanciation) yaitu dunia realitas yang dibangun oleh unsur-unsur copy, replica, replication, imitation, likeness, dan reproduction dari unsur-unsur kebudayaan masa lalu yang dihadirkan dalam konteks masa kini sebagai sebuah nostalgia (Amir Piliang, 2009). Aktifitas spiritual bukan lagi merepresentasikan nilai-nilai spiritual objektif tapi sudah membentuk dunianya sendiri sebagai ajang personalitas gaya, mode, dan trend bahkan pada tataran yang lebih tinggi telah menciptakan kesombongan-kesombongan akan merasa benar sendiri atau baik sendiri dalam dunia keberagamaan dan praktek-prakteknya. Tanda-tanda praktek ibadah ini adalah ia berasal dari imajinasi diri yang tidak berujung pada teks-teks agama atau tanpa merujuk pada imajinasi kenabian, yakni kesadaran akan sisi nubuat dari ajaran agama yang dibawanya.

Hiperrealitas spiritual atau hiperspiritualitas telah menciptakan praktek-praktek ibadah yang dibangun berdasarkan simulasi ritual yang kelihatan asli seperti yang diajarkan nabi padahal ia merupakan ritual bentukan yang jauh dari ajaran ayat-ayat suci yang diajarkan nabi dan rasul. Dalam kajian hipersemiotika, ritual-ritual bentukan atau simulasi itu merupakan tanda-tanda palsu atau dusta yang jauh dari tanda-tanda objektif yang mengacu pada objek ritual itu sendiri. Pada tataran ini, tanda-tanda praktek ibadah yang didasarkan pada simulasi telah mematikan makna sesungguhnya dari tanda tersebut. Karena tanda-tanda praktek ibadah berdasarkan simulasi atau daya imajinasi diri, maka yang muncul adalah kepalsuan, kedustaan, serta kebohongan atas tandatanda praktek ibadah tersebut. Implikasinya, tanda-tanda ibadah sebatas ritual keberagamaan dan tidak memiliki pengaruh pada tindakan sosial seseorang. Praktek ibadah hanya sebatas tanda-tanda untuk menutupi tanda-tanda lain yang dimiliki seseorang yang bertolak belakang dengan makna sesungguhnya dari praktek-praktek ibadah yang ia lakukan. Praktek ibadah telah dicemari oleh polusi imajinasi diri yang sarat kepalsuan, pencitraan, dan personalitas gaya keberagamaan.

Perlu dipahami dalam kajian ilmu-ilmu agama, khususnya yang berhubungan dengan tanda dan komunikasi, seperti dalamkasus praktek-raktek ibadah, bahwa ada tanda-tanda yang wajib diterima secara ideologis yang bersifat transenden, akan tetapi ada pula tanda-tanda atau kode yang pada kenyataannya telah diterima secara sosial sebagai sesuatu keputusan final, dan diikuti secara taqlid, padahal sesungguhnya tanda-tanda dan kode tersebut terbuka bagi interpretasi, bagi dekonstruksi, atau istilah syariatnya dikenal dengan ijtihad (Amir Piliang, 2012). Jika di satu sisi tanda-tanda praktek ibadah bisa merepresentasikan kepatuhan, kekhusyuan, dan kepasrahan, maka di sisi lain praktek ibadah itu juga bisa menggambarkan ketidakpedulian, acuh tak acuh, dan ketidaktaatan. Dalam pandangan Eco, jika tanda bisa merepresentasikan kebenaran, maka tanda juga harus bisa merepresentasikan kedustaan dan kebohongan.

Praktek-praktek ibadah yang didasarkan pada imajinasi diri pada kajian postspiritualitas adalah kondisi di mana nilai-nilai spiritual bercampur aduk dengan nilai-nilai materialisme, bersekutunya yang duniawi dengan yang ilahiah, bersimpang-siurnya yang transenden dengan yang imanen, bertumpang-tindihnya hasrat rendah dengan kesucian sehingga perbedaan menjadi kabur. Realitas ibadah hanyalah realitas bentukan atau simulasi, ajang permainan citra, dan jauh dari realitas dan makna ibadah yang sesungguhnya. Ibadah tak ubahnya seperti musik yang memiliki efek khusus. Dalam musik ada efek-efek yang diciptakan lewat teknologi sehingga suara yang dihasilkannya bukanlah asli tapi artifisial. Namun demikian, suara artifisial mengambil alih suara yang asli. Seperti 
dalam musik, dalam agama terdapat ritual yang sesungguhnya bukan bagian dari ritual, tai ia mengambil alih ritual utama dan asli. Dalam kehidupan beragama terdapat pembauran antara gaya hidup dengan ritual, yang profan dengan yang spiritual atau sakral. Pembauran ini terjadi dalam aspek ritual keagamaan, seperti puasa, zakat, haji, wacana spiritualitas, perayaan hari besar keagamaan, tayangan keagamaan di televisi dan lain-lain (Amir Piliang, 2012).

Praktek-praktek ibadah dalam kajian postspiritualitas pada akhirnya hanyalah tanda-tanda bisu, mati, dan tidak bermakna. Dalam praktek ibadah terdapat ritual-ritual bentukan yang menggantikan ritual yang sesungguhnya. Ritual-ritual bentukan membentuk dunianya sendiri dianggap asli, namun tanpa disadari menggantikan ritual praktek-praktek ibadah yang sesungguhnya. Dalam pemikiran Baudrilliard, istilah ini dikenal dengan hiperrealitas. Dalam dunia hiperrealitas, antara realitas dan simulasi sudah sulit dibedakan (Agger, 2009). Pada akhirnya, pada wilayah spiritual bentukan, yang muncul adalah hiperspiritualitas (spiritual bentukan atau rekayasa). Ritual bentukan hasil simulasi lebih eksis dari ritual yang sesungguhnya. Pada wilayah ini, makna kekhusyuan dan kepatuhan telah mati, gugur, dan hancur bersama ritual yang sesungguhnya. Pada akhirnya yang muncul adalah kepatuhan palsu dan kekhusyuan yang tersimulasi.

\section{Tafsir Identitas-Identitas Ibadah}

Setelah melalui proses imajinasi diri dan imajinasi nubuat untuk memperoleh makna yang hakiki dari praktek ibadah, apa yang harus dilakukan manusia agar praktek-praktek ibadah sesuai dengan nilai-nilai spiritual yang digariskan oleh Yang Maha Kuasa. Untuk menjawab pertanyaan ini, kita harus mengetahui makna ibadah itu sendiri serta identitas-identas yang melekat padanya. Dalam pandangan Piliang, kalau kehidupan di dunia ini sudah diketahui sebelumnya, tidak ada misteri kehidupan yang akan terjadi, tidak ada kehidupan dunia, yang ada hanyalah kehidupan yang tidak bermakna. Dunia hidup jika ada yang tidak diketahui dibaliknya (Amir Piliang, 2004). Begitu juga dianalogikan dengan praktek ibadah. Bila manusia tahu bahwa praktek ibadahnya diterima atau tidak diterima, maka praktek ibadah menjadi tidak bermakna. Mengembalikan makna spiritualitas atau praktek ibadah berarti seseorang mengakui ada sisi misteri dibalik ibadahnya. Yang mengetahui apakah ibadah seseorang diterima atau tidak, hanyalah Tuhan. Pada wilayah inilah ibadah menjadi bermakna, dan dalam konteks seperti ini kepatuhan dan kekhusyuan seseorang manusia akan muncul.

Pada kajian postspiritualitas dan hiperspiritualitas ketika praktek-praktek ibadah telah menemukan jati diri dan eksistensinya, praktek ibadah akan menemukan makna hakikinya. Ibadah memiliki makna hakiki jika belum diketahui apakah ibadah seseorang diterima atau tidak. Hanya Tuhan yang tahu. Pada tataran ini, praktek ibadah menemukan eksistensi dan jati dirinya. Ketika praktek ibadah menemukan jati dirinya, ia akan jauh dari mesin reproduksi kesombongan, keangkuhan, dan merasa benar sendiri.

Memaknai praktek ibadah dan identitas-identitas yang mengikutinya sangat penting untuk mendapatkan pemahaman yang baik serta jauh dari sekedar daya imajinasi diri. Daya imajinasi diri sesungguhnya adalah modal menuju imajinasi nubuat bisa melaksanakan ibadah yang sejati dan kegiatan-kegiatan spiritual menuju kepatuhan dan kepasrahan hakiki kepada Tuhan. Interpretasi dan memaknai ayat-ayat Tuhan juga membutuhkan proses imajinasi diri dan imajinasi nubuat. Dalam proses pemaknaan praktek-praktek ibadah, imajinasi diri tidak dapat dipisahkan dari imajinasi nubuat. Imajinasi diri merupakan landasan filosofis menuju imajinasi nubuat untuk mendapatkan makna yang benar dari praktek ibadah dan ayat-ayat Tuhan. Praktek ibadah akan menjadi hakiki dan benar serta bebas dari kotoran-kotoran duniawi, jika pemahaman dan pelaksanaannya dikembalikan kepada makna aslinya. Pelaksanaan ibadah pada awalnya memiliki makna objektif dalam arti pelaksanaan ibadah adalah bentuk realisasi dari perintah Tuhan yang di dalamnya mengandung nilai-nilai kepatuhan, kepasrahan, dan realisasi bentuk cinta makhluk kepada penciptanya.

Realitas makna objektif praktek ibadah akan bergeser ke realitas bentukan jika makna ibadah berganti menjadi pengharapan atau profit semata (mendapatkan surga dan terhindar dari siksa neraka). Pergeseran makna selanjutnya yang lebih rendah lagi adalah jika praktek ibadah diselimuti 
kepentingan identitas-identitas duniawi seperti personalitas gaya spiritual, status sosial keagamaan, terlebih lagi juga sudah terselip tujuantujuan untuk mendapatkan nilai-nilai materi di balik makna objektif keagungan doa, dan kesucian praktek ibadah. Ketika doa dikonstruksi menjadi sekedar praktek spiritual untuk mendapatkan kelancaran hidup duniawi di situlah makna kekhusyuan, kepatuhan, dan kepasrahan kepada Tuhan telah mati. Pada tataran ini, susah dibedakan antara mantra dengan doa, antara kepatuhan dengan pembangkangan, antara kepasrahan dengan mengesampingkan.

Dalam kajian postspiritualitas, hiperspiritualitas, dan postkomunikasi makna praktek ibadah yang sudah bergeser ke makna personalitas gaya untuk mencapai identitas-identitas spiritual tertentu dalam kehidupan sosial keagamaan, telah membentuk realitas-realitas baru yang jauh dari realitas utama. Proses konstruksi makna ibadah oleh pelakunya yang sudah bergeser dari makna sebenarnya akan berujung pada banalitas spiritual ketika pelaku-pelaku ibadah sudah mengkonstruksi berbagai macam makna baru yang palsu. Praktek ibadah dikonstruksi untuk tujuan pencitraan, pencarian kelancaran duniawi semata, dan makna-makna atau tujuan-tujuan lain yang sudah bergeser dari makna aslinya. Dalam bahasa Selu Margaretha Kushendrawati, banalitas telah menciptakan makna-makna yang tidak berbobot (Margaretha Kushendrawati, 2011).

\section{Tafsir Ayat-Ayat Tuhan}

Menafsirkan teks-teks al-Qur'an dalam kajian postmodernitas, post spiritualitas, dan postkomunikasi perlu kehati-hatian. Pesan-pesan Tuhan memilki makna tekstual (denotasi) dan kontekstual (makna konotasi). Ayat-ayat Tuhan merupakan tanda (sign) yang memerlukan perpaduan daya imajinasi diri dan imajinasi nubuat untuk memahaminya. Daya imajinasi diri dan imajinasi nubuat merupakan satu kesatuan proses dalam memahami dan memaknai pesan-pesan Tuhan. Daya imajinasi diri merupakan kekuatan nalar manusia dalam bingkai kesadarannya untuk memaknai pesan-pesan Tuhan atas apa yang telah diwahyukan Tuhan kepada nabi dengan kekuatan imajinasi nubuatnya. Makna denotasi pesan-pesan Tuhan adalah makna apa adanya dari pesan tersebut. Makna konotasi teks (ayat-ayat) adalah makna teks yang sudah dikaitkan dengan fakta historis, yakni tempat teks atau ayat tersebut diturunkan, serta waktu teks tersebut diturunkan. Di samping itu, sangat perlu mengaitkan teks atau ayat-ayat Tuhan dengan sosio kultural di mana teks tersebut turun. Analogi indeks, ikon, simbol, dan bahasa-bahasa metafora sangat diperlukan untuk memaknai ayat-ayat atau pesan Tuhan.

Menafsirkan atau memahami ayat-ayat Tuhan dalam pandangan Piliang melibatkan tiga pihak: Tuhan, Nabi atau rasul, dan Manusia (umat). Dalam proses pemaknaan ini terdapat petanda transendental dan harus diperhatikan untuk mendapatkan penafsiran yang produktif dan inovatif sehingga makna pesan tersebut bisa hidup sepanjang zaman (Amir Piliang, 2004). Dengan adanya ketiga pihak ini, proses pemaknaan teks tidak saja membutuhkan identitas "human communication" tapi juga memahami proses komunikasi transendental. Nabi dan rasul yang memiliki petanda "human communication" sekaligus memiliki petanda "imajinasi nubuat" serta Tuhan dengan petanda "transendental" keduanya titik sentral manusia untuk memahami teks-teks Tuhan.

Bila ditinjau lebih jauh, ayat-ayat Tuhan terdiri dari ayat-ayat yang berkaitan dengan ketuhanan (tauhid) dan ayat-ayat yang bukan berkaitan dengan ketuhanan. Bila ayat-ayat Tuhan dianggap sebagai tanda, maka metode yang digunakan untuk membedah tanda adalah semiotika. Semiotika adalah ilmu tentang tanda. Semiotika dapat digunakan sebagai alat bedah untuk menafsirkan tandatanda Tuhan dalam bentuk teks-teks al-Quran. Meskipun belum sempurna, tapi metode ini minimal bisa menyampaikan makna-makna teks Tuhan baik pada tataran tekstual (denotasi) atau pun kontekstual (konotasi). Pada wilayah konotasi, tidak semua teks Tuhan ditafsirkan secara bebas seperti kata Derrida. Pada tataran konotasi, teks-teks yang bisa ditafsirkan hanyalah teks-teks yang tidak berkaitan dengan tauhid (ketuhanan) dalam arti teks yang bisa ditafsirkan bebas seperti konsep neraka, surga, dosa, dan lain-lain. Semiotika untuk membongkar teks-teks Tuhan termasuk semiotika teologis (semiotika ketuhanan). Dalam semiotika teologis, penafsiran masih harus berpijak pada petanda transendental atau tanda-tanda ilahiah. 
Pada proses pembedahan teks-teks Tuhan secara semiotika, teks-teks Tuhan memiliki makna terbatas secara denotasi atau makna yang lebih luas secara konotasi. Pemaknaan secara semiotika harus mengacu pada pemaknaan secara imajinasi nubuat dan rasul. Dengan metode analisis Barthes, pada tataran wilayah konotasi, teks-teks Tuhan terbuka untuk berbagai pemaknaan. Teks-teks Tuhan juga mengandung banyak bahasa-bahasa metafora. Monroe Beardsley mengatakan metafora adalah sebuah puisi miniatur. Dengan begitu, hubungan antara makna literal dan makna figuratif dalam sebuah metafora adalah seperti sebuah kalimat tunggal yang memiliki makna yang kompleks dalam satu karya literer. Karya literer berbeda dari karya wacana lain, khususnya wacana sains, di mana ia membawa makna eksplisit dan implisit ke dalam suatu hubungan (Ricour, 2012). Pada akhirnya, ketika praktek ibadah telah lepas dari aslinya dan membentuk simulasi maka praktek ibadah hanyalah ajang pencitraan, personalitas gaya, dan mesin reproduksi kesombongan. Pencitraan merupakan salah satu kegiatan untuk membentuk citra. Dalam pandangan Bill Canton, citra merupakan: "Image is the impression, the feeling, the conception, which the public has company a conciously created impression of an object, person or an organization" (Yentin Mediana, 2017). Mengembalikan praktek ibadah kepada aslinya dengan melaksanakan perintah praktek-praktek ibadah sesuai imajinasi nubuat dan rasul, praktek ibadah harus jauh dari tujuan-tujuan duniawi dan materi, praktek ibadah haruslah merupakan bukti kecintaan makhluk kepada Khalik.

\section{Simpulan}

Agama tidak bisa hidup tanpa peran imajinasi, termasuk imajinasi tentang yang transenden. Akan tetapi, imajinasi yang melampaui batas telah membentuk kreativitas-kreativitas dalam pengamalan agama yang mungkin menyimpang dari tujuan pengamalan ibadah itu sendiri. Kajian postspiritualitas, hiperspiritualitas, dan postkomunikasi menemukan bahwa makna berbagai praktek ibadah di era modern ini sudah bergeser ke makna personalitas gaya untuk mencapai identitasidentitas spiritual tertentu dalam kehidupan sosial keagamaan. Pergeseran itu telah membentuk realitas-relaitas baru (bentukan) yang jauh dari realitas utama (praktek spiritual untuk kepatuhan dan kepasrahan kepada tuhan).

\section{Referensi}

Agger, B. (2009). Teori Sosial Kritis: Kritik, Penerapan, dan Implikasinya. Kreasi Wacana.

Amir Piliang, Y. (2004). Dunia yang Dilipat: Tamasya Melampaui Batas-batas Kebudayaan. Jalasutra.

Amir Piliang, Y. (2009). Retakan-retakan Kebudayaan: Antara Keterbatasan dan Ketakberhinggaan. Melintas: An International Journal of Philosophy and Religion, 25(1), 82.

Amir Piliang, Y. (2011). Bayang-bayang Tuhan: Agama dan Imajinasi. PT Mizan Publika.

Amir Piliang, Y. (2012). Semiotika dan Hipersemiotika: Kode, Gaya, dan Matinya Makna. Matahari.

Barthes, R. (2015). Mitologi Roland Barthes. Kreasi Wacana.

Fitria, H. (2015). Hiperrealitas dalam Social Media, Studi Kasus Makan Cantik di Senopati pada Masyarakat Perkotaan. Informasi: Kajian Ilmu Komunikasi, 45(2), 83-100.

Green, S. A., Billinghurst, M., Chen, X., \& Chase, J. G. (2008). Human-robot collaboration: A literature review and augmented reality approach in design. International Journal of Advanced Robotic Systems, 5(1), 1.

Hendrawan, H., Solina, E., \& Elsera, M. (2018). Hiperrealitas Pengguna Instagram di Lingkungan FISIP Universitas Maritim Raja Ali Haji.

Kloos, B., \& Moore, T. (2000). The prospect and purpose of locating community research and action in religious settings. Journal of Community Psychology, 28(2), 119-137.

Margaretha Kushendrawati, S. (2011). Hiperrealitas Dan Ruang Publik: Sebuah Analisis Cultural Studies. Penaku.

Nasrullah, R., \& Rustandy, D. (2016). Meme dalam Islam: Simulakra Bahasa Agama di Media Sosial. Ilmu Dakwah: Academic Journal for Homiletic Studies, 10(1), 113-128.

Regnerus, M. D., \& Uecker, J. E. (2007). Religious influences on sensitive self-reported behaviors: The product of social desirability, deceit, or embarrassment? Sociology of Religion, 68(2), 145-163.

Ricour, P. (2012). Teori Interpretasi: Memahami Teks, Penafsiran, dan Metodologinya. IRCiSoD.

W. Suhaeb, F., \& Ashabul Kahfi, M. (2016). Fenomena Hiperrealitas Masyarakat pada Makanan. Prosiding Eminar Nasional Pendidikan Ilmu-Ilmu Sosial, 315-320. 
Wahyuningsih, H. (2008). Religiusitas, Spiritualitas, dan Kesehatan Mental: Meta Analisis. Psikologika: Jurnal Pemikiran Dan Penelitian Psikologi, 13(25), 61-72.

Winangsih Syam, N. (2014). Komunikasi Peradaban. Rosda Karya.

Yentin Mediana, F. (2017). Media Sosial dan Hiperrealitas Hary Tanoesoedibjo sebagai Politikus Religius Islam. UIN Sunan Kalijaga.

(C) 2020 by the authors. Submitted for possible open access publication under the terms and conditions of the Creative Commons Attribution (CC BY SA) license (https://creativecommons.org/licenses/by-sa/3.0/). 